\title{
BRPKM
}

Buletin Riset Psikologi dan Kesehatan Mental

http://e-journal.unair.ac.id/index.php/BRPKM

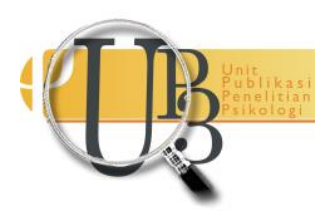

ARTIKEL PENELITIAN

\section{Hubungan antara Keberfungsian Keluarga dan Dukungan Sosial Teman Sebaya dengan Subjective Well-Being (Studi pada Remaja yang Mengalami Stres di Masa Pandemi COVID-19)}

\author{
SITI ROCHMA \& NURUL HARTINI*
}

Departemen Psikologi Klinis dan Kesehatan Mental, Fakultas Psikologi Universitas Airlangga

\begin{abstract}
ABSTRAK
Pandemi COVID-19 memiliki dampak psikologis stres bagi remaja yang memengaruhi subjective wellbeing. Penelitian ini bertujuan untuk mengetahui apakah terdapat hubungan antara keberfungsian keluarga dan dukungan sosial teman sebaya terhadap subjective well-being remaja yang mengalami stres di masa pandemi COVID-19. Penelitian dilakukan menggunakan pendekatan kuantitatif dengan teknik pengumpulan data berupa survei. Sebanyak 212 partisipan remaja berusia 14-21 tahun yang diperoleh melalui metode purposive sampling. Hasil dari penelitian ini menunjukkan bahwa terdapat hubungan yang negatif antara keberfungsian keluarga dengan subjective well-being $(\mathrm{r}=0,151, \mathrm{p}=0,028)$, terdapat hubungan yang positif antara dukungan sosial teman sebaya dengan subjective well-being $(\mathrm{r}=0,285, \mathrm{p}=0,001)$, dan terdapat hubungan positif dan signifikan antara keberfungsian keluarga dan dukungan sosial teman sebaya dengan subjective well-being $\mathrm{p}=0,000$ atau $\mathrm{p}<0,05$ dan $\mathrm{F}=9,456>\mathrm{F}$ tabel 3,04 . Penelitian ini menambahkan variansi baru bahwa keberfungsian keluarga dan dukungan sosial teman sebaya secara bersama-sama mampu memprediksi subjective well-being sebesar 8,3\%.
\end{abstract}

Kata Kunci: dukungan sosial teman sebaya, keberfungsian keluarga, subjective well-being

\begin{abstract}
COVID-19 pandemic has a psychological impact of stress on adolescents that affects subjective wellbeing. This study aims to determine the correlation between family functioning and peer social support on the subjective well-being of adolescents experiencing stress during the COVID-19 pandemic. This study uses quantitative approach with survey technique. This study involved 212 adolescent participants aged 14-21 years who were recruited using purposive sampling method. The results showed a negative correlation between family functioning and subjective well-being ( $\mathrm{r}=-0.151$, $\mathrm{p}=0.028)$, a positive correlation between peer social support and subjective well-being $(\mathrm{r}=0,285$, $\mathrm{p}=0,001$ ), and a significant and a positive correlation between family functioning and peer social support with subjective well-being $p=0,000(p<0,05)$ and $F=9,456>F$ table 3,04. This research adds a new variance that family functioning and peer social support together are able to predict subjective well-being by $8.3 \%$.
\end{abstract}

Keywords: family functioning, peer social support, subjective well-being 
Naskah ini merupakan naskah dengan akses terbuka dibawah ketentuan the Creative Common Attribution License (CC-BY-4.0) (http://creativecommons.org/licenses/by/4.0), sehingga penggunaan, distribusi, reproduksi dalam media apapun atas artikel ini tidak dibatasi, selama sumber aslinya disitir dengan baik.

\section{PEN D A H U L U A N}

Adanya pandemi membuat pemerintah menerapkan sejumlah kebijakan untuk melandaikan kurva peningkatan penyebaran COVID-19 diantaranya yaitu; menggalakkan pola hidup bersih dan sehat, menjaga jarak, bekerja dari rumah, belajar dari rumah, pembatasan sosial berskala besar (PSBB) (Kemenkes, 2020). Pada sektor pendidikan, lebih dari 130 negara kini telah menutup sekolah secara nasional, yang berdampak pada hampir 80\% siswa di seluruh dunia. Di Indonesia terdapat sekitar 65 universitas yang menyediakan pembelajaran dari rumah (Pragholapati, 2020). Pandemi COVID-19 tidak hanya berdampak pada kesehatan fisik namun juga berdampak pada kesehatan mental dan kondisi psikososial seseorang termasuk bagi remaja yang berstatus sebagai siswa dan mahasiswa yang menjalani pembelajaran dari rumah.

Pandemi menyebabkan adanya rasa ketakutan akan ketidakpastian yang dapat menyebabkan adanya stres psikologis (Vinkers, dkk., 2020). Salah satu faktor penyebab stres remaja dikarenakan siswa merasa kesulitan belajar di rumah (Ananda \& Apsari, 2020). Para siswa merasa bosan, lelah, dan seringkali terjadi miskomunikasi antara siswa dan guru. Berdasarkan survei yang dilakukan KPAI, 79,9\% anak mengakui bahwa interaksi mereka berkurang serta memiliki tugas yang berat sehingga anak berada di bawah tekanan yang lebih besar sedangkan 20,1\% anak berpendapat bahwa mereka masih mampu berinteraksi. Hartini (2009) stres yang dialami individu dapat menurunkan sistem kekebalan (imunitas tubuh).

Individu yang merasakan lebih sedikit stres akan memiliki subjective well-being tinggi dibandingkan dengan individu yang merasakan lebih banyak stres (Nezlek dkk., 2019). Stres yang dialami individu tentu akan berdampak memengaruhi subjective well-being dan hal tersebut semakin mengkhawatirkan (Holmes dkk., 2020). Hal tersebut menjelaskan bahwa subjective well-being merupakan hal penting yang perlu dimiliki oleh setiap remaja. Subjective well-being didefinisikan oleh Diener (2000) sebagai evaluasi individu terhadap kesejahteraan psikologis yang dialaminya. Subjective well-being dipengaruhi oleh berbagai faktor diantaranya: faktor pendidikan, agama, penghasilan, kecerdasan, dan relasi dengan individu lainnya, faktor yang sangat memengaruhi subjective well-being yaitu keberfungsian keluarga (Nayana, 2013). Keberfungsian keluarga sangat mempengaruhi subjective well-being remaja karena keberfungsian keluarga mempengaruhi sosio-emosional remaja, dimana kondisi sosio-emosional remaja tidak stabil dan seringkali rentan (Nayana, 2013). Memainkan peran interaksi keluarga dalam proses melaksanakan tugas-tugas penting untuk menjaga pertumbuhan dan kesejahteraan (well-being) setiap anggota keluarga (Walsh 2003).

Pandemi menimbulkan dampak negatif pada kehidupan keluarga yakni adanya tekanan yang diakibatkan dari kecemasan terhadap kesehatan keluarga, konflik antar keluarga dan kehilangan kontak fisik dengan keluarga lain dan teman (Fleming dan O'Hara, 2020). Pandemi mampu menjadikan hubungan dengan keluarga semakin erat karena memiliki lebih banyak waktu dirumah serta orang tua memiliki kesempatan untuk lebih mengenal anak-anaknya (Fleming \& O'Hara, 2020). Kondisi fungsi keluarga seperti itu dapat memengaruhi kesejahteraan anggota keluarga dan dengan demikian mengarah pada hubungan positif antara anggota keluarga sekaligus sebagai faktor penentu kondisi subjective well-being individu. 
Faktor lain yang dapat mempengaruhi subjective well-being seseorang adalah dukungan sosial. Dukungan sosial dari orang lain dapat meningkatkan kehidupan sehari-hari individu; misalnya ketika individu menghadapi suatu masalah, dukungan sosial dapat diberikan dalam bentuk dorongan, saran, dan pendapat untuk membantu individu tersebut keluar dari masalah yang dialaminya (Tarigan, 2018). Sumber dukungan sosial antara lain berasal dari dukungan keluarga, dukungan teman sebaya, dan dukungan dari kelompok tertentu (Sarafino \& Smith, 2011).

Hurlock (Kumalasari dan Nur, 2012) menunjukkan bahwa remaja menerima lebih banyak dukungan sosial dari teman sebayanya. Memiliki hubungan dengan teman sebaya membuat remaja merasa nyaman dan merasa mendapat dukungan. Interaksi dengan teman sebaya merupakan komponen penting dalam perkembangan sosial masa remaja (Nisa, 2012). Kondisi pandemi COVID-19 mewajibkan remaja baik siswa maupun mahasiswa untuk menjalankan belajar dari rumah sehingga interaksi dengan teman berkurang.

Penelitian ini dilakukan sebagai bentuk tindak lanjut dari penelitian sebelumnya untuk melihat hubungan dari kedua variabel, keberfungsian keluarga dan dukungan teman sebaya terhadap subjective well-being. Terlebih penelitian tentang subjective well-being terhadap remaja di masa pandemi COVID19 menjadi penting karena pandemi memiliki dampak psikologis bagi remaja.

\section{Desain Penelitian}

\section{MET O D E}

Penelitian ini menggunakan pendekatan kuantitatif menggunakan survei yang diedarkan melalui media sosial WhatsApp, Line, Instagram, dan Twitter.

\section{Partisipan}

Penelitian menggunakan teknik purposive sampling. Partisipan penelitian ini adalah remaja berusia 1421 tahun, sedang menjalani belajar dari rumah, dan sedang mengalami stres. Form kesediaan untuk berpartisipasi diedarkan secara online melalui media sosial WhatsApp, Line, Instagram, dan Twitter.

\section{Pengukuran}

Penelitian ini menggunakan lima skala pengukuran sebagai berikut. Alat ukur tingkat stres berdasarkan teori stres Sarafino (2008) berisi 32 aitem digunakan untuk mengukur tingkat stres individu. Lima poin skala Likert dari 1 (Tidak Pernah) hingga 5 (Sangat Sering). Semakin besar nilai mengarah pada semakin tinggi tingkat stres. Hasil reabilitas skala diukur dengan teknik Cronbach's alpha sebesar $(\alpha=0,67)$.

Keberfungsian keluarga diukur menggunakan skala Family Assessment Device berdasarkan konsep McMaster Family Functioning oleh Epstein Baldwin, dan Bishop (1983) yang menggambarkan persepsi seseorang terhadap keluarga mereka. Skala berisi 53 aitem 4 poin skala Likert dari 1 (Sangat Sesuai) hingga (Sangat Tidak Sesuai). Skala memiliki koefisien reabilitas skala tinggi sebesar $(\alpha=0,91)$.

Dukungan sosial teman sebaya diukur menggunakan skala yang mengacu pada jenis dukungan sosial menurut Cobb (1976). Skala berisi 32 aitem 4 poin skala Likert dari 1 (Sangat Sesuai) hingga (Sangat Tidak Sesuai). Skala dukungan sosial teman sebaya memiliki koefisien reabilitas skala tinggi sebesar $(\alpha=0,91)$.

Subjective well-being diukur dengan menggunakan skala Satisfaction With Life Scale (SWLS) terdiri dari 5 aitem oleh Dinner, dkk (1985) dan Positive Affect and Negative Affect Scale (PANAS) Watson, Clark,

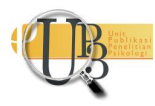


dan Tellegen (1988) terdiri dari 20 komponen afektif. Skala dengan 4 poin skala Likert dari 1 (Sangat Sesuai) hingga (Sangat Tidak Sesuai). Skala Satisfaction With Life Scale (SWLS) memiliki koefisien reabilitas sebesar $(\alpha=0,71)$ dan Positive Affect and Negative Affect Scale (PANAS) memiliki koefisien reabilitas sebesar $(\alpha=0,78)$.

Analisis Data

Data penelitian dianalisis menggunakan teknik pearson correlation dari IBM SPSS for Windows versi 26.

\section{HAS I L P EN EL I T I A N}

Partisipan yang terlibat dalam penelitian ini didominasi oleh mahasiswa $(81,1 \%)$ dan pelajar $(18,9 \%)$. Sebagian besar parstisipan menjalani belajar dari rumah selama 7 bulan.

Tabel 1. Statistik Deskriptif (N=212)

\begin{tabular}{lccc}
\hline \multicolumn{1}{c}{ Variabel } & Range & M & SD \\
\hline Keberfungsian Keluarga & 101 & 119,82 & 16,41 \\
Dukungan Sosial Teman Sebaya & 52 & 73,43 & 8,77 \\
Subjective Well-Being & 41 & 20,00 & 7,24 \\
\hline
\end{tabular}

Variabel keberfungsian keluarga memiliki nilai range sebesar 101, variabel dukungan sosial teman sebaya nilai range sebesar 52 dan variabel subjective well-being nilai range sebesar 41. Nilai rata-rata (mean) variabel keberfungsian keluarga sebesar 119,82 dengan nilai standar deviasi 16,41. Variabel dukungan sosial teman sebaya nilai rata-rata (mean) sebesar 73,43 dengan nilai standar deviasi 8,77. Variabel subjective well-being nilai rata-rata (mean) sebesar 20,00 dengan nilai standar deviasi 7,24.

Tabel 2. Korelasi Pearson

\begin{tabular}{cccc}
\hline Variabel Y & Variabel X1, X2 & $\begin{array}{c}\text { Correlation Coefficient } \\
\text { Sig. (2-tailed) }\end{array}$ & Sig \\
\hline Subjective Well-Being & Keberfungsian Keluarga & $-0,151$ & 0,028 \\
& Dukungan Sosial Teman Sebaya & 0,285 & 0,001 \\
\hline
\end{tabular}

Berdasarkan tabel 2 variabel keberfungsian keluarga dengan subjective well-being memiliki nilai signifikansi sebesar 0,028 dan koefisiensi korelasi -0,151. Sedangkan pada variabel dukungan sosial teman sebaya dengan subjective well-being memiliki nilai signifikansi sebesar 0,001 dan koefisiensi korelasi 0,285. Keberfungsian keluarga dengan subjective well-being memiliki hubungan yang negatif sedangkan dukungan sosial teman sebaya dengan subjective well-being memiliki hubungan yang positif. 
Tabel 3. Regresi Berganda

\begin{tabular}{cccc}
\hline & R Square & F & Sig. \\
\hline Regression & 0,083 & 9,456 & 0,000 \\
\hline
\end{tabular}

Tabel 4. Model Coefficient Regresi Berganda

\begin{tabular}{lccccc}
\hline \multirow{2}{*}{ Model } & \multicolumn{2}{c}{$\begin{array}{c}\text { Unstandardized } \\
\text { Coefficients }\end{array}$} & $\begin{array}{c}\text { Standardized } \\
\text { Coefficients }\end{array}$ & t & Sig, \\
\cline { 2 - 4 } & B & Std, Error & Beta & & \\
\hline (Constant) & 6,229 & 6,849 & & 0,910 & 0,364 \\
KK & $-0,020$ & 0,032 & $-0,046$ & $-0,634$ & 0,527 \\
DS & 0,220 & 0,059 & 0,267 & 3,705 & 0,000 \\
\hline
\end{tabular}

Ringkasan analisis regresi pada tabel 3 menunjukkan nilai Sig. sebesar 0,000 atau <0,05 dengan nilai F hitung sebesar 9,456 >nilai $\mathrm{F}$ tabel 3,04. Keberfungsian keluarga dan dukungan sosial teman sebaya secara simultan memprediksi terhadap subjective well-being. Nilai $R$ Square sebesar 0,083 atau 8,3\% nilai variabel subjective well-being dapat dijelaskan oleh variabel keberfungsian keluarga dan dukungan sosial teman sebaya. Berdasarkan hasil analisis regresi berganda nilai koefisiensi beta pada keberfungsian keluarga sebesar -0,046 dan nilai koefisiensi beta pada dukungan sosial teman sebaya sebesar 0,267. Nilai Sig. daya prediksi keluarga dan subjective well-being sebesar 0,527 atau >0,05 dan nilai t hitung -0,634 < t tabel 1,971, sehingga keberfungsian keluarga tidak dapat memprediksi subjective well-being secara signifikan. Adapun nilai Sig. daya prediksi dukungan sosial teman sebaya dan subjective well-being sebesar 0,000 atau $<0,05$ dan nilai $t$ hitung 3,705 $>\mathrm{t}$ tabel 1,971, sehingga dukungan sosial teman sebaya dapat memprediksi subjective well-being secara signifikan.

\section{I S K U S I}

Hasil penelitian menunjukkan bahwa terdapat hubungan negatif antara keberfungsian keluarga dan subjective well-being. Hasil dari penelitian ini bertolak belakang dengan hasil dari penelitian-penelitian sebelumnya yang mengatakan bahwa tingkat keberfungsian keluarga berhubungan positif dengan subjective well-being remaja (Nayana, 2013). Penelitian sebelumnya menyimpulkan bahwa subjective well-being akan berubah sesuai dengan kondisi kehidupan seseorang.

Salah satu faktor yang dapat menjelaskan mengapa keberfungsian keluarga dan subjective well-being tidak berhubungan mungkin diakibatkan oleh adanya perbedaan konteks penelitian. Shek (1997) individu dengan masalah kondisi mental memiliki pandangan negatif terhadap keluarganya. Karakteristik subjek pada penelitian ini adalah subjek yang memiliki tingkat stres sedang dan tinggi yang mana subjek sudah jelas memiliki masalah dengan kondisi mentalnya. Kedua, pandemi membawa dampak negatif pada kehidupan keluarga yang mampu menimbulkan tekanan pada keluarga (Fleming \& O'Hara, 2020). Ketiga, dampak dari adanya pandemi membawa pengaruh berupa kedekatan remaja dan keluarga yang dipaksakan, dimana pada usia remaja ini mereka berusaha untuk menjadi mandiri dan lebih banyak bersosialisasi dan menghabiskan waktu bersama temannya (Janssen dkk., 2020). Keempat, kategori subjek pada penggolongan distibusi pada skala alat ukur Family Asessment Device

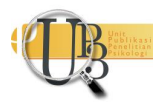


lebih banyak pada kategori sedang karena pada saat pengisian kuesioner lebih banyak memilih skala likert pada angka 2 dan 3, yang menunjukkan bahwa subjek lebih cenderung memilih jawaban aman dalam mengisi kuesioner.

Hasil penelitian menunjukkan bahwa terdapat hubungan positif antara dukungan sosial teman sebaya dan subjective well-being. Hasil penelitian ini sejalan dengan penelitian Fajarwati (2014) bahwa menunjukkan terdapat hubungan positif antara dukungan sosial dan subjective well-being pada remaja. Ketika individu mempunyai masalah, dukungan sosial yang diberikan oleh orang lain dapat menghilangkan stres dan memberikan manfaat bagi individu tersebut (Rif'ati dkk., 2018).

Dukungan sosial teman sebaya memiliki pengaruh tinggi terhadap subjective well-being (Fajarwati, 2014). Dukungan tersebut dapat diperoleh baik secara emosional, informasional, penghargaan, maupun emosional. Hurlock (1993) remaja memiliki subjective well-being yang lebih tinggi yang diperoleh dari dukungan teman sebaya dikarenakan remaja menghabiskan banyak waktu dan lebih dekat dengan kelompok. Remaja melakukan banyak kegiatan dengan teman sebayanya, mereka saling terbuka, mampu memberikan semangat serta motivasi. Pada penelitian ini remaja yang mengalami stres di masa pandemi memiliki subjective well-being pada kategori sedang dan tinggi sebanyak $89,2 \%$ dari jumlah responden dan sebesar 10,8\% pada kategori rendah, sehingga dapat diketahui bahwa walaupun remaja mengalami stres namun masih memiliki tingkat subjective well-being yang baik.

Hasil penelitian juga menunjukkan terdapat hubungan positif antara keberfungsian keluarga dan dukungan sosial teman sebaya dengan subjective well-being. Hubungan positif menjelaskan bahwa keberfungsian keluarga dan dukungan sosial teman sebaya secara simultan memprediksi terhadap subjective well-being. Pada keberfungsian keluarga meskipun berkorelasi tapi tidak dapat digunakan untuk memprediksi subjective well-being. Hal tersebut dikarenakan dukungan sosial teman sebaya saja menyumbang sebagian besar dan sudah cukup untuk memprediksi $8.3 \%$ varian subjective well-being. Hubungan dengan teman sebaya memberikan dampak besar terhadap subjective well-being remaja (Nickerson dan Nagle, 2004). Maleicki dkk., (dalam Tian dkk., 2015) dukungan sosial teman sebaya merupakan salah satu hal utama dalam keseharian remaja terkait dengan dukungan sosial. Dukungan sosial teman sebaya berimplikasi besar tehadap subjective well-being remaja di lingkungan.

Nilai $R$ Square yang didapatkan cenderung kecil yakni sebesar 8.3\% menunjukkan bahwa selain keberfungsian keluarga dan dukungan sosial teman sebaya, terdapat faktor lain yang dapat berkorelasi dan memprediksi subjective well-being pada remaja ialah individu yang mampu beradaptasi terhadap lingkungannya. Individu yang mampu beradaptasi dengan baik akan dapat menghadapi kejadiankejadian dalam kehidupannya dengan baik sehingga mampu membuat subjective well-being menjadi lebih lebih (Tarigan, 2018). Beberapa faktor lain yang dapat memengaruhi subjective well-being individu yaitu harga diri yang positif, rasa kontrol, optimisme, perasaan terhadap makna dan tujuan, ekstroversi, serta hubungan sosial yang positif (Nayana, 2013).

\section{S I M P U L A N}

Penelitian ini memperoleh kesimpulan bahwa terdapat hubungan yang negatif antara keberfungsian keluarga dengan subjective well-being pada remaja yang mengalami stres di masa pandemi COVID-19. Terdapat hubungan yang positif antara dukungan sosial teman sebaya dan subjective well-being pada remaja yang mengalami stres di masa pandemi COVID-19. Terdapat hubungan yang positif antara keberfungsian keluarga dan dukungan sosial teman sebaya terhadap subjective well-being pada remaja yang mengalami stres di masa pandemi COVID-19. Hubungan positif tersebut menjelaskan bahwa 
keberfungsian keluarga dan dukungan sosial teman sebaya secara simultan memprediksi terhadap subjective well-being. Pada keberfungsian keluarga meskipun berkorelasi tapi tidak dapat digunakan untuk memprediksi subjective well-being. Hal tersebut dikarenakan dukungan sosial teman sebaya saja menyumbang sebagian besar dan sudah cukup memprediksi subjective well-being.

\section{DEKLARASI POTENSI TERJADINYA KONFLIK KEPENTINGAN}

Siti Rochma tidak bekerja, menjadi konsultan, memiliki saham, atau menerima dana dari perusahaan atau organisasi manapun yang mungkin akan mengambil untung dari diterbitkannya naskah ini.

\section{PUSTAKA ACUAN}

Ananda, S. S. D., \& Apsari, N. C. (2020). Mengatasi Stress Pada Remaja Saat Pandemi Covid-19 Dengan Teknik Self Talk. 7(2), 248-256.

Diener, E. (2000). Subjective well-being: The science of happiness and a proposal for a national index. American Psychologist, 55(1), 34-43.

Fajarwati, D. I. (2014). Hubungan dukungan sosial dan subjective wellbeing pada remaja smpn 7 yogyakarta. Universitas Islam Negeri Sunan Kalijaga, Fakultas Ilmu sosial dan Humaniora.

Fleming, P., \& O'Hara, J. (2020). Impact on family life during Covid-19 pandemic. Barnardos, 2-6.

Hartini, N. (2009). Bencana Tsunami dan Stres Pasca-Trauma pada Anak. Masyarakat, Kebudayaan Dan Politik, 22(3), 259-264.

Holmes, E. A., O'Connor, R. C., Perry, V. H., Tracey, I., Wessely, S., Arseneault, L., Ballard, C., Christensen, H., Cohen Silver, R., Everall, I., Ford, T., John, A., Kabir, T., King, K., Madan, I., Michie, S., Przybylski, A. K., Shafran, R., Sweeney, A., ... Bullmore, E. (2020). Multidisciplinary research priorities for the COVID-19 pandemic: a call for action for mental health science. The Lancet Psychiatry, 7(6), 547560.

Hurlock, E. B. (1993). Psikologi perkembangan: suatu pendekatan sepanjang rentang kehidupan. Jakarta: Erlangga.

Janssen, L. H. C., Kullberg, M. L., Verkuil, B., van Zwieten, N., Wever, M. C. M., van Houtum, L. A. E. M., Wentholt, W. G. M., \& Elzinga, B. M. (2020). Does the COVID-19 pandemic impact parents' and adolescents' well-being? An EMA-study on daily affect and parenting. PLOS ONE, 15(10 October), $1-21$.

Kementrian Kesehatan Republik Indonesia. (2020). KMK No. HK.01.07-MENKES-413-2020 tentang Pedoman Pencegahan dan Pengendalian COVID-19 (pp. 31-34).

Kumalasari, F., Pengajar, S., \& Psikologi, F. (2012). Hubungan Antara Dukungan Sosial Dengan Penyesuaian Diri Remaja Di Panti Asuhan Latifah Nur Ahyani. Jurnal Psikologi Pitutur, 1(1), 22-31.

Nayana, F. N. (2013). KEFUNGSIAN KELUARGA DAN SUBJECTIVE WELL-BEING PADA REMAJA. Jurnal Ilmiah Psikologi Terapan, 66(1997), 37-39.

Nezlek, J. B., Krejtz, I., Rusanowska, M., \& Holas, P. (2019). Within-Person Relationships Among Daily Gratitude, Well-Being, Stress, and Positive Experiences. Journal of Happiness Studies, 20(3), 883- 
898.

Nickerson, A. B., \& Nagle, R. J. (2004). The influence of parent and peer attachments on life satisfaction in middle childhood and early adolescence. Social Indicators Research, 66(1-2), 35-60.

Nisa, R. A. K. (2012). Sumbangan Self-Esteem, Dukungan Orang Tua, Guru, Dan Teman Sebaya Terhadap Kepuasan Sekolah Pada Siswa Tunarungu Di Smp Dan Sma/Smk Inklusi. Universitas Indonesia, Fakultas Psikologi.

Pragholapati, A. (2020). Covid-19 Impact on Students. 1-6.

Rif ati, Mas I.; Arumsari, Azizah; Fajriani, Nurul; Maghfiroh, Virgin S.; Abidi, Ahmad F.; Chusairi, Achmad; Hadi, C. (2018). Konsep Dukungan Sosial. Jurnal Psikologi, 15(29), 7577-7588.

Sarafino, E. P., \& Smith, T. W. (2011). Health Psychology: Biopsychosocial Interaction (7th Ed). New York: John Wiley and Sons.

Shek, D. T. L. (1997). The Relation of Family Functioning to Adolescent Psychological Well-Being, School Adjustment, and Problem Behavior. Journal of Genetic Psychology, 158(4), 467-479.

Tarigan, M. (2018). Hubungan Dukungan Sosial dengan Subjective Well-Being pada Remaja yang Memiliki Orangtua Tunggal. Jurnal Diversita, 4(1), 1-8.

Tian, L., Zhao, J., \& Huebner, E. S. (2015). School-related social support and subjective well-being in school among adolescents: The role of self-system factors. Journal of Adolescence, 45(1), 138-148.

Vinkers, C. H., van Amelsvoort, T., Bisson, J. I., Branchi, I., Cryan, J. F., Domschke, K., Howes, O. D., Manchia, M., Pinto, L., de Quervain, D., Schmidt, M. V., \& van der Wee, N. J. A. (2020). Stress resilience during the coronavirus pandemic. European Neuropsychopharmacology, 35, 12-16.

Walsh, F. (2012). Changing families in a changing world; Reconstructing family normality. Dalam Froma Walsh (Ed.), Normal family processes (3rd edition):growing diversity and complexity (pp. 7). New York: The Guilford Press. 